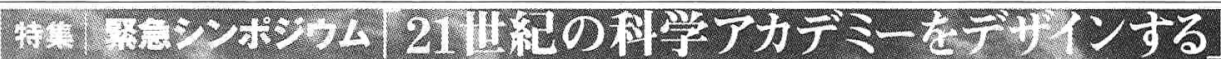

各国アカデミー講演「科学アカデミーの役割と機能」

Royal Swedish Academy of Sciences
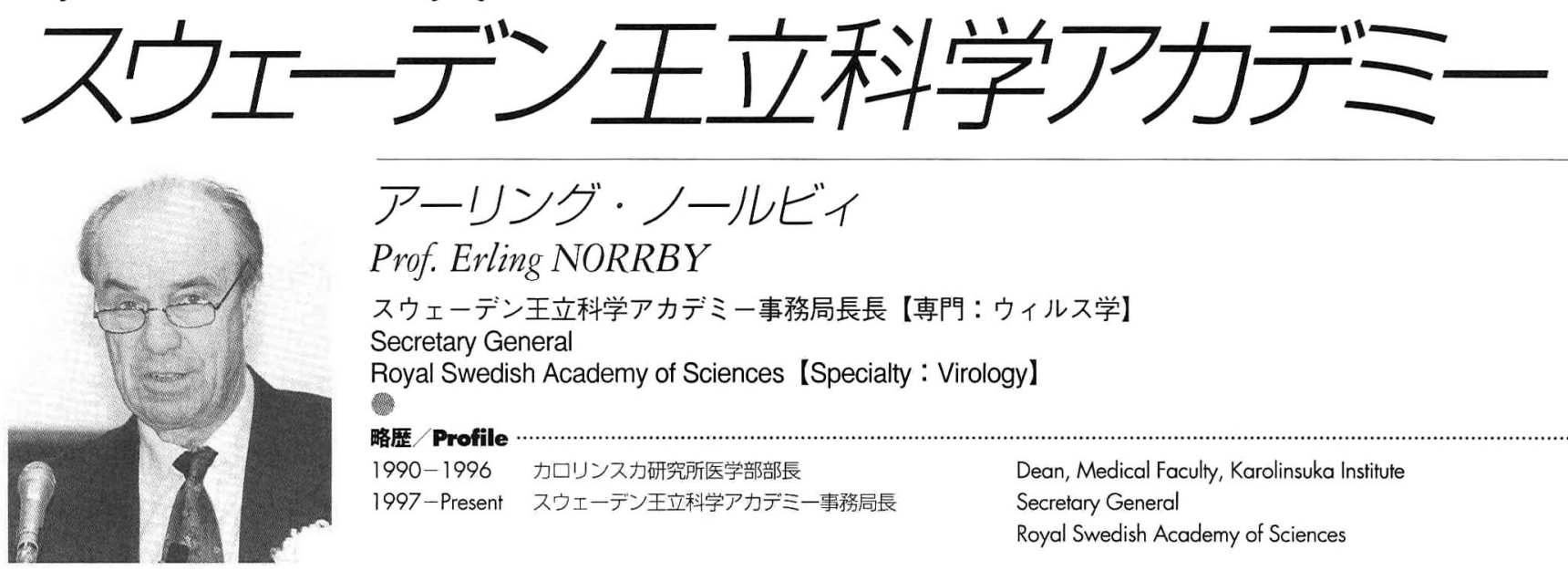

アーリング・ノールビイ

Prof. Erling NORRBY

スウェーデン王立科学アカテミミー事務局長長【専門：ウィルス学】

Secretary General

Royal Swedish Academy of Sciences【Specialty : Virology】

略歴 Profile

1990-1996 カロリンスカ研究所医学部部長

1997-Presentスウエーデン王立科学アカデミー事務局長

Dean, Medical Faculty, Karolinsuka Institute

Secretary General

Royal Swedish Academy of Sciences
スウェーデン王立科学アカデミーは1739年に設 立された。5人の創立者には何人かの著名な科学者、 特にCarl von Linneが含まれていた。本アカデミー は定員制で、10部門に員数が割り当てられている。 今日、この定員は 164 人である。いずれかの部門の ある会員が65歳になると、同じ部門に新しい会員を 選出することができる。しかし、先任会員は自己の すべての権利を保持している。したがって、全体で スウェーデン人会員の数は約 350 人にのぼる。これ に対し、外国人会員には年齢規則がなく、したがっ て、その会員数は164 人である。

本アカデミーの会員はかけがえのない財産を体現 するものである。一連の活動によって、会員は本ア カデミーに共感をもち、専門分野の枠を超えて他の 会員と交流し、本アカデミーの指導部によって開始 されたプロジェクトに参加するように奨励される。 アカデミー会員である常勤の事務局長、本アカデミ 一の法律顧問及び1人の会長と 3 人の副会長が本ア カデミーの運営に責任をもっている。後者の4人は 名誉職である。

総運営費の $25 \%$ 未満が政府によって提供されて いる。資金のほとんどは本アカデミー自身の基金か
ら得られているが、特別なプロジェクトには外部か らの補助金が使われる。本アカデミーは、広範な分 野の任務をもつ7つの研究所を運営している。これ らのいくつかは独自の基金によって資金を調達して いる。

定款の定めにより、本アカデミーは「科学、特に 数学と自然科学の進歩を促進する」こととされてい る。したがって、10部門のうち8部門は数学から技 術に至るまでの学術分野を担っている。一方、残り の2 部門は経済学・社会科学と人文科学を対象とし ている。なお、スウェーデンには他に7つのアカデ ミ一があり、その中には、王立文学・歴史学・考古 学アカデミーやスウェーデン王立工学アカデミーが 含まれている。

本アカデミーの主たる使命はスウェーデンの研究 政策に影響を及ぼすことである。この点に関し、本 アカデミーは首相及び教育相と密に連携している。 教育相は 2000 年 9 月にスウェーデンの長期科学計画 を発表した際、その発表を本アカデミーで行った。 本アカデミーは教育省にプロジェクトを提案し、教 育省から委託を受けることができる。

第二の使命は科学者に直接支援を提供することで 


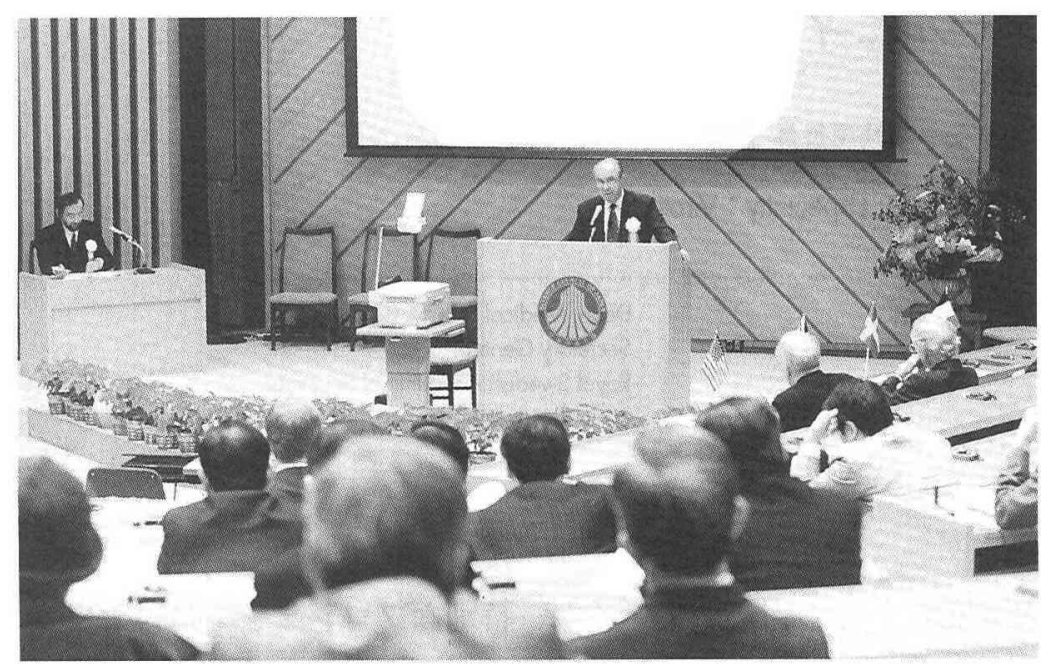

ある。その他、国際賞及び数種の国内賞 がある。

第三の使命は国際協力を推進すること である。これは多国間及び二国間の協定 によって、また研究所に扔いて外国人客 員科学者に魅力的な条件を提供すること によって、行われている。

第四の使命は学校で数学と自然科学に 対する関心を刺激することである。これ は、例えば、新しい教授法や教材を開発

ある。その一部は本アカデミーの研究所で行われて 拈り、これらの研究所は多くの客員科学者と在留科 学者を受け入れることができるが、それに加えて、 本アカデミー自身の基金からの資金を使った、ある いは外部から調達した資金を使った直接的な資金援 助も行われている。経歴の浅い科学者に特に重点が 置かれている。

本アカデミーはまた、科学的業績に対し賞をもつ て顕彰している。本アカデミーからの最も有名な賞 は、ノーベル物理学賞と化学賞、アルフレッド・ノ ーベルを記念した経済学賞及びクラフォールド賞で
した教師に賞を授与したり、新しい教授法の実践に ついて教師を教育したり、ノーベル賞の業績を説明 するポスターを作成することなど、多くの方法で行 われている。

最後に、本アカデミーはまた、好奇心をそそる科 学の進歩について人々に情報を提供している。これ は公開講演会や会議を主催したり、本を出版したり （例えば、「人間と新しい生物学」シリーズ）、イ ンターネットで情報を提供することなどによって行 われている。

\section{Abstrat of Leciure}

The Royal Swedish Academy of Sciences was established in 1739. The five founding fathers included some notable scientists, in particular Carl von Linne. The Academy has a fixed number of members which are allocated in quotas to ten different classes. Today this number is 164 . When a member of any of the classes turns 65 a new member can be elected to the same class. However, senior members retain all their rights. Thus, in total the number of Swedish members is about 350 . By way of contrast there is no age rule for foreign members, which therefore number 164 .

The members of the Academy represent a unique asset. By a range of activities members are stimulated to identify with the Academy, to interact with other members across borders of disciplines and to engage 
in projects initiated by the leadership team of the Academy. The secretary general, which is a full-time employed academician, the Academy's legal advisor, and one president and three vice presidents are responsible for the management of the Academy. The latter four individuals hold honorary positions only.

Less than $25 \%$ of the total running costs are provided by the government. Most of the resources come from the Academy's own foundations, but external grants are mobilized for specific projects. The Academy runs seven institutions with widely ranging domains of responsibility. Some of these are financed by their own endowment.

The statutes of the Academy specify that she shall "further the advance of science, in particular mathematics and natural sciences". Thus, eight of the ten classes are responsible for disciplines ranging from mathematics to technical sciences. However the two remaining classes are for economics and social sciences and for humanities. Still there are seven other academies in Sweden including the Royal Academy of Letters, History and Antiquities and the Royal Swedish Academy of Engineering Sciences.

The primary mission of the Academy is to influence the research policy of Sweden. In this matter the Academy interacts closely with the Prime Minister and the Minister of Education. When the latter minister in September 2000 announced the long range plans for science in Sweden he did this at the Academy. The Academy can initiate projects towards and receive commissions from the Ministry of Education.

The secondary mission is to give direct support to scientists. This is partly done at the Academy's institutions, which can host many visiting scientists and scientists in residence, but also by direct financial support by use of money from the Academy's own foundations or by recruitment of money from external sources. A particular attention is paid to scientists in the early phase of their career.

The Academy also rewards scientific achievement by prizes. The most well-known prizes from the Academy are the Nobel Prizes in Physics or Chemistry, the Prize in Economy in Memory of Alfred Nobel and the Crafoord Prize. There are also other international and several national prizes.

The third mission is to foster international collaborations. This is done both by multilateral and by bilateral arrangements and by providing attractive conditions for foreign visiting scientists at the institutions.

The forth mission is to stimulate the interest for mathematics and natural sciences in schools. This is done in many ways as for example by giving prizes to teachers developing new pedagogy, develop materials and educate teachers to allow new pedagogic approaches, make posters describing Nobel Prize achievements.

Finally, the Academy also informs the public of the exciting advances of science. This is done by arranging open lectures, conferences, publishing books (e.g. a series "Man and the new biology"), providing information on the web etc.

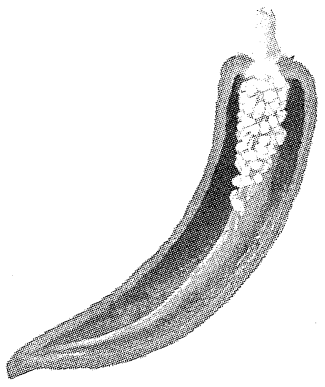

